\title{
Relative importance of acid coating on ice nuclei in the deposition and contact modes for wintertime Arctic clouds and radiation
}

\author{
Eric Girard • Niloofar Sokhandan Asl
}

Received: 20 March 2013/Accepted: 9 November 2013/Published online: 27 November 2013

(C) The Author(s) 2013. This article is published with open access at Springerlink.com

\begin{abstract}
Aerosols emitted from volcanic activities and polluted mid-latitudes regions are efficiently transported over the Arctic during winter by the large-scale atmospheric circulation. These aerosols are highly acidic. The acid coating on ice nuclei, which are present among these aerosols, alters their ability to nucleate ice crystals. In this research, the effect of acid coating on deposition and contact ice nuclei on the Arctic cloud and radiation is evaluated for January 2007 using a regional climate model. Results show that the suppression of contact freezing by acid coating on ice nuclei leads to small changes of the cloud microstructure and has no significant effect on the cloud radiative forcing (CRF) at the top of the atmosphere when compared with the effect of the alteration of deposition ice nucleation by acid coating on deposition ice nuclei. There is a negative feedback by which the suppression of contact freezing leads to an increase of the ice crystal nucleation rate by deposition ice nucleation. As a result, the suppression of contact freezing leads to an increase of the cloud ice crystal concentration. Changes in the cloud liquid and ice water contents remain small and the CRF is not significantly modified. The alteration of deposition ice nucleation by acid coating on ice nuclei is dominant over the alteration of contact freezing.
\end{abstract}

Responsible editor: R. Roebeling.

E. Girard $(\bowtie) \cdot$ N. Sokhandan Asl

Department of Earth and Atmospheric Sciences, ESCER Centre,

University of Quebec at Montreal, PO Box 8888, Station

Downtown, Montreal, QC H3C 3P8, Canada

e-mail: girard.eric@uqam.ca

\section{Introduction}

The Arctic is highly polluted during the cold season with high concentrations of aerosols being often observed (Schnell 1984; Yli-Tuomi et al. 2003; Law and Stohl 2007). These aerosols, which are mainly emitted over northern European cities, China, and Siberia (Shaw 1995), are transported from the mid-latitudes to the Arctic by large-scale atmospheric circulations (Bourgeois and Bey 2011; Fisher et al. 2011; Barrie et al. 1989; Shaw 1995). This transport is favored by the southward progression of the polar front during winter in the Northern Hemisphere. Anthropogenic aerosols are emitted north of the front in an environment with little precipitation, resulting in limited loss of aerosols by wet deposition. The aerosol component consists of a significant fraction of highly acidic sulphate, and previous work has shown that almost all of the submicron aerosol particles are coated with this highly acidic sulphate (Bigg 1980; Cantrell et al. 1997).

Laboratory studies have shown that acid coating on wellknown efficient ice nuclei (IN) such as dust particles has a substantial effect on their ability to nucleate ice crystals in the deposition mode. For instance, Eastwood et al. (2009) have shown that the onset relative humidity with respect to ice at which ice nucleation occurs on sulphuric acid-coated kaolinite particles is substantially increased when compared with uncoated kaolinite particles. Ice nucleation on sulphuric acid-coated kaolinite particles is therefore energetically much more difficult. Similar results were also obtained in other laboratory studies (Ettner et al. 2004; Archuleta et al. 2005; Knopf and Koop 2006; Salam et al. 2007; Cziczo et al. 2009; Sullivan et al. 2010; Chernoff and Bertram 2010; Niedermeier et al. 2010).

The above-mentioned laboratory studies have focused on deposition ice nucleation and immersion freezing. In the 
former case, ice nucleation occurs on a solid particle from the vapor phase, while in the latter case ice nucleation occurs on a solid particle immersed in either an aqueous solution in sub saturated air with respect to liquid water (un-activated haze droplet) or in an activated cloud water droplet. According to Pruppacher and Klett (1997), two other ice nucleation modes are also possible. In the condensation-freezing mode, an aerosol particle at temperatures below $0{ }^{\circ} \mathrm{C}$ acts as $\mathrm{CCN}$ to form a drop which freezes at some time during the condensation stage. Finally, in the contact mode, ice nucleation occurs on a solid particle in contact with a water droplet.

Previous modeling studies have shown that acid coating on deposition IN can have a substantial effect on ice and mixed-phase cloud microstructure and radiative forcing over the Arctic during the cold season (Girard et al. 2005; $\mathrm{Du}$ et al. 2011; Girard et al. 2013). Acid coating on deposition IN leads to the formation of fewer and larger ice crystals. Ice clouds are therefore optically thinner and their vertical structure is more uniform with similar concentration of precipitating crystals throughout the cloud. Uncoated deposition IN lead to the formation of ice clouds composed by a larger concentration of small ice crystals with the largest ice crystal concentration near cloud top. These studies have also shown that mixed-phase cloud frequency is increased when IN are coated with sulphuric acid. Radiatively, the combined effects of the increased emissivity of mixed-phase clouds and the increased transmissivity of the optically thinner upper ice clouds result in a decrease of the cloud radiative forcing (CRF) at the top of the atmosphere (TOA) and a tropospheric cooling ranging between 0 and $3 \mathrm{~K}$. Jouan et al. $(2012,2013)$ have also shown from in situ measurements, back trajectory and remote sensing tools, the relationship between acid coating on IN and ice cloud microphysical properties mentioned above for ice cloud cases observed over the North Slope of Alaska in 2007.

In the above-mentioned modeling studies, it was assumed that contact freezing was not altered by the sulphuric acid coating on IN. Although no evidence exists yet from laboratory studies, it is also likely that sulphuric acid coating equally affects contact freezing. Once fully immersed in a solution, the direct contact between the IN and a water droplet is not possible anymore, unless the ice nucleus is only partially immersed. However, other contact freezing processes remain possible. Several observations in cumuli and stratiform clouds have reported an enhancement of ice crystals in regions where cloud droplets evaporate (Hobbs and Rangno 1985; Cooper 1986, 1995; Beard 1992; Rangno and Hobbs 1994; Field et al. 2001; Cotton and Field 2002; Ansmann et al. 2005; Baker and Lawson 2006). It has been hypothesized that contact freezing could occur in the contact mode during evaporation. Based on these observations, Durant and Shaw (2005) have performed laboratory experiments and shown that contact freezing also occurs from the inside-out. It is reasonable to assume that the inside-out contact freezing would also be altered by sulphuric acid coating. Indeed, according to Sullivan et al. (2010), the de-activation effect of sulphuric acid on dust particles is irreversible and is still active once the acid is highly diluted or neutralized. Therefore, contact freezing is likely to be altered even in the inside-out contact freezing.

Morrison et al. (2005) have assessed the relative importance of contact freezing and deposition ice nucleation using a 1D model. They found that contact freezing was the dominant ice nucleation mechanism in mixedphase clouds due to the rapid depletion of deposition IN. The self-regulatory behavior of contact freezing in mixedphase clouds contributes to the formation of long-lived co-existence of liquid and ice. In their study, neither deposition nor contact IN were coated by sulphuric acid. It should be noted that immersion freezing of activated water droplets was neglected in their simulations. Other studies in laboratory and field experiments suggest that the freezing nucleation dominates over the deposition nucleation (e.g., Ansmann et al. 2009; Field et al. 2006). Finally, some studies have shown that deposition ice nucleation is the dominant nucleation mode and that contact freezing is only a minor contributor in Arctic mixed-phase clouds (Harrington et al. 1999; Harrington and Olsson 2001).

This study aims to assess the relative importance of ice nucleation modes both in clean (uncoated IN) and polluted (sulphuric acid-coated IN) air masses over the Arctic during a winter month. In Sects. 2 and 3, the model and the experimental set-up are described. Results are described in Sect. 4 and discussed in Sect. 5. A conclusion follows in Sect. 6.

\section{Model description}

The Global Environmental Multiscale (GEM) model is used in this study. The numerical formulation of GEM can be found in Côté et al. (1998). The physics package includes the radiation scheme of $\mathrm{Li}$ and Barker (2005) and the surface scheme Interactions Soil-Biosphere-Atmosphere (ISBA) developed by Noilhan and Planton (1989). Stratiform precipitation is parameterized using a modified version of the Milbrandt and Yau (2005) microphysics scheme. The modifications made to the parameterizations of ice nucleation processes are described below.

This is a two-moment microphysics scheme. The hydrometeors are divided into six classes including cloud droplets, cloud ice crystals, raindrop, snow, graupel and 
hail. The hydrometeor size distribution is described by a gamma function, $N(D)=N_{0} D^{\alpha} e^{-\lambda D}$, in which $N_{0}$ and $\lambda$ are referred to the intercept and the slope, $D$ is the diameter of hydrometeors and $\lambda$ is the spectral shape parameter that has a constant value. The parameterizations used to simulate other microphysical processes can be found in Milbrandt and Yau (2005).

Deposition and condensation freezing are a function of ice supersaturation following Meyers et al. (1992). Contact freezing is parameterized following Cotton et al. (1986) and Walko et al. (1995), in which the number concentration of contact IN is parameterized as a function of temperature following Meyers et al. (1992). Immersion freezing of activated rain and cloud water droplets follows the parameterization of Bigg (1953). The parameterization for homogeneous freezing of water droplets follows DeMott et al. (1994).

Substantial modifications have been made to the original version of the microphysics scheme to account for the heterogeneous ice nucleation on both uncoated and coated IN. Four modes of heterogeneous ice nucleation are represented in this modified version of the microphysics scheme: deposition ice nucleation, contact freezing, immersion and condensation freezing of un-activated haze droplets, immersion freezing of activated cloud droplets. No modifications have been made to the original scheme for the parameterization of contact freezing. Deposition ice nucleation on uncoated IN and immersion freezing of sulphuric acid-coated IN are parameterized following Girard et al. (2013). These parameterizations are based on the classical nucleation theory (CNT) of Fletcher (1962). In the CNT, the nucleation rate depends on the contact angle between the ice embryo and the IN. The contact angle is derived based on the laboratory experiments of Eastwood et al. $(2008,2009)$ on uncoated $\left(\theta=12^{\circ}\right)$ and sulphuric acid-coated $\left(\theta=27^{\circ}\right)$ kaolinite particles. The concentration of ice crystals $\left(N_{\mathrm{i}}\right)$ nucleated in a given time step $(\Delta t)$ is given by:

$N_{\mathrm{i}}=N_{\text {dust }}[1-\exp (-J(\theta) A \Delta t)]$

where $J$ is the nucleation rate, $N_{\text {dust }}$ is the concentration of dust particles and $A$ is the dust surface area.

The CNT approach with a constant contact angle has been evaluated and compared to other ice nucleation parameterizations by Du et al. (2011) for the simulation of the clouds and radiation observed during the Surface Heat and Energy Budget of the Arctic (SHEBA) campaign. Results show that this approach simulates quite well the cloud liquid and ice water paths and the CRF at the surface, in particular during the polar night. For this reason and because the contact angle PDF (probability density function) for sulphuric acid-coated dust particles is not available, the constant contact angle approach is used in this study. It should be noted that the PDF approach for the contact angle has been tested for our simulations and the results are very close to the constant angle approach in terms of CRF and temperature.

\section{Numerical configuration}

In this study, the integration domain is rectangular $(9,100 \mathrm{~km} \times 7,700 \mathrm{~km})$ and is centered over the Arctic. It covers all areas north of $50^{\circ} \mathrm{N}$ including the Arctic Ocean, the North Atlantic and Pacific Oceans, most of Europe, Northern Asia, Iceland, Greenland, Siberia and Northern Canada. The horizontal resolution is $0.25^{\circ}$ with 364 latitudinal grid points and 308 meridional grid points including a 12-point sponge zone. Results are analyzed on a sub-domain of $8,500 \mathrm{~km}$ by $7,100 \mathrm{~km}$ to eliminate the sponge zone. The simulations are performed with 53 vertical levels from 1,000 to $10 \mathrm{hPa}$ with the highest resolution in the lower levels. The initial and lateral boundary conditions are provided by the European Centre Meteorological Weather Forecasting Centre (ECMWF) analysis data. The analyzed fields are available on 18 pressure levels $(1,000,925,850,775,700,600,500,400$, $300,250,200,150,100,70,50,30,20$ and $10 \mathrm{hPa})$ on a longitude/latitude grid with a $2^{\circ}$ by $2^{\circ}$ spatial resolution at every 6 h (i.e. at 00, 06, 12 and 18 GMT) for December 2006 and January 2007. The variables are then interpolated to the GEM grid. Sea ice and sea surface temperature are from AMIP2 (Atmospheric Model Intercomparison Project) (Hurrell et al. 2008). They are available on a grid at a horizontal resolution of $1^{\circ}$ by $1^{\circ}$. They are then interpolated to the GEM grid. Cubic and linear interpolations are used in space and time, respectively.

The model internal variability for the Arctic climate is relatively high during winter (Rinke et al. 2004; Girard and Bekcic 2005). Hence, a large number of simulations are required to distinguish the investigated climate signal from the model internal variability. Each simulation within an ensemble is initialized with different conditions by advancing or retreating the initial data by $12 \mathrm{~h}$ following Rinke and Dethloff (2000). In our experiments, ten simulations of each aerosol scenario were performed.

Table 1 shows the simulated aerosol scenarios with their acronyms. There are four aerosol scenarios: NAT-ON is an aerosol scenario in which there is no acid coating on IN with the contact freezing set to ON, NAT-OFF is similar except that the contact freezing is set to OFF, AC-ON assumes that there is acid coating on IN with contact freezing set to $\mathrm{ON}$, and $\mathrm{AC}-\mathrm{OFF}$ is similar to $\mathrm{AC}-\mathrm{ON}$ except that contact freezing is set to OFF. The other ice nucleation modes considered are: deposition ice nucleation for the NAT scenarios and immersion freezing of coated IN for the AC scenarios. 
Table 1 Contact angle, contact freezing, acid coating and modes of ice nucleation in the four aerosol scenarios used in the simulations

\begin{tabular}{|c|c|c|c|c|}
\hline & NAT-ON & NAT-OFF & AC-ON & AC-OFF \\
\hline Contact freezing & Yes & No & Yes & No \\
\hline $\begin{array}{c}\text { Immersion } \\
\text { freezing }\end{array}$ & No & No & Yes & Yes \\
\hline $\begin{array}{c}\text { Deposition } \\
\text { freezing }\end{array}$ & Yes & Yes & No & No \\
\hline Acid coating & No & No & Yes & Yes \\
\hline Contact angle $\left(^{\circ}\right)$ & $\begin{array}{l}\text { Constant } \\
12\end{array}$ & $\begin{array}{c}\text { Constant } \\
12\end{array}$ & $\begin{array}{c}\text { Constant } \\
27\end{array}$ & $\begin{array}{c}\text { Constant } \\
27\end{array}$ \\
\hline
\end{tabular}

Immersion freezing refers to unactivated haze droplets. Immersion freezing of activated cloud droplets is allowed in all scenarios

Some assumptions are made for the concentration of dust particles ( $N_{\text {dust }}$ in Eq. 1) and their spatial and temporal variabilities. Following Girard et al. (2013), a constant value in time and space $\left(0.38 \mathrm{~cm}^{-3}\right)$ for $N_{\text {dust }}$ is assumed since the model does not simulate aerosol transport and physics. This means that there are no sources and sinks of dust particles. Girard et al. (2013) have evaluated the sensitivity of the model results to the aerosol concentration for the NAT-ON and AC-ON aerosol scenarios. They found that the NAT-ON scenario was quite sensitive to $N_{\text {dust }}$, while the AC-ON scenario was not sensitive to $N_{\text {dust }}$ because the Gibbs free energy for the formation of the ice embryo is much larger in AC-ON. Although the assumed concentration is representative of past observations (Girard et al. 2013), the dust concentration is highly variable in both time and space and may reach larger values and/or much smaller values. Furthermore, it is assumed that kaolinite is representative of the atmospheric dust particles in terms of ice nucleation ability. Finally, the dust radius used in our simulations is $0.5 \mu \mathrm{m}$.

\section{Results}

Figure 1 shows the mean sea level pressure for January 2007 from the ECMWF analysis. There is a low-pressure system with two centers: one located north of Scandinavia and the second one just south of Greenland. A third lowpressure system is located over the Aleutians and a strong anticyclone dominates over Siberia. This synoptic pattern favors the transport of aerosols and warmer air from the mid-latitudes to the Arctic through East Asia and Alaska. Table 2 shows the January mean MSLP (mean sea level pressure), temperature at $850 \mathrm{hPa}$ and geopotential height at $500 \mathrm{hPa}$ from the ECMWF analysis and the model simulations with the four aerosol scenarios. These values are averaged over a sub-domain deliminated by the sea ice boundaries. The sea ice boundary is defined as the southward grid point with more than $50 \%$ sea ice cover north of $60^{\circ} \mathrm{N}$ (see Fig. 1). Grid points with less than $50 \%$ sea ice were excluded from the mask. The MSLP from all aerosol scenarios is slightly overestimated by $2-4 \mathrm{hPa}$. The temperature at $850 \mathrm{hPa}$ is well reproduced with biases of $<1 \mathrm{~K}$. Finally, the geopotential height at $500 \mathrm{hPa}$ is also well captured by the model with biases of $<3 \mathrm{dam}$. Overall, the model simulates quite well the main atmospheric variables for January 2007.

Figure 2 shows the January mean vertical profiles of the ice water content and ice crystal number concentration averaged over the sea ice mask mentioned above. As expected, the ice water content and the ice crystal number concentration substantially decrease in both acid-coated aerosol scenarios AC-ON and AC-OFF when compared with the uncoated aerosol scenarios NAT-ON and NATOFF. These results are in agreement with the results obtained by Girard et al. (2013) for January and February 2007. In the AC aerosol scenarios, the ice crystal nucleation rate is substantially reduced in the immersion mode due to the larger contact angle associated to the acid coating on the IN. The effect of contact freezing on the ice water content and crystal number concentration in NAT (NAT-ON and NAT-OFF) and AC scenarios (AC-ON and AC-OFF) is small. Surprisingly, contact freezing contributes to slight decrease of both the ice water content and the ice crystal number concentration in the NAT scenarios and to a lesser extent in the $\mathrm{AC}$ scenarios.

Figure 3 shows the January mean vertical profile of the liquid water content and droplet number concentration averaged over the sea ice mask for the four aerosol scenarios. In the AC aerosol scenarios, the liquid water content and number concentration of cloud droplets substantially increase by one order of magnitude. This is consistent with the results obtained in Girard et al. (2013). Contact freezing has a negligible effect in the NAT scenario and a small effect in the AC scenario with an increase of the liquid water content and droplet number concentration, when contact freezing is set to ON.

The increase of liquid water content and the decrease of the ice water content, when contact freezing is set to $\mathrm{ON}$, are somewhat counter intuitive. One possible explanation is a negative feedback by which the contribution of contact freezing would lead to a decrease of ice nucleation by deposition. Deposition ice nucleation strongly depends on the relative humidity with respect to ice. A potential change in the deposition ice nucleation rate must necessarily be seen through a change in the relative humidity with respect to ice.

Figure $4 \mathrm{a}$ and $\mathrm{b}$ show the January mean vertical profiles of relative humidity with respect to ice averaged over the sea ice mask for NAT-ON and NAT-OFF and for AC-ON and AC-OFF, respectively. In the NAT aerosol scenarios, 
Fig. 1 Mean sea level pressure (MSLP in $\mathrm{hPa}$ ) form the ECMWF analysis averaged over January 2007

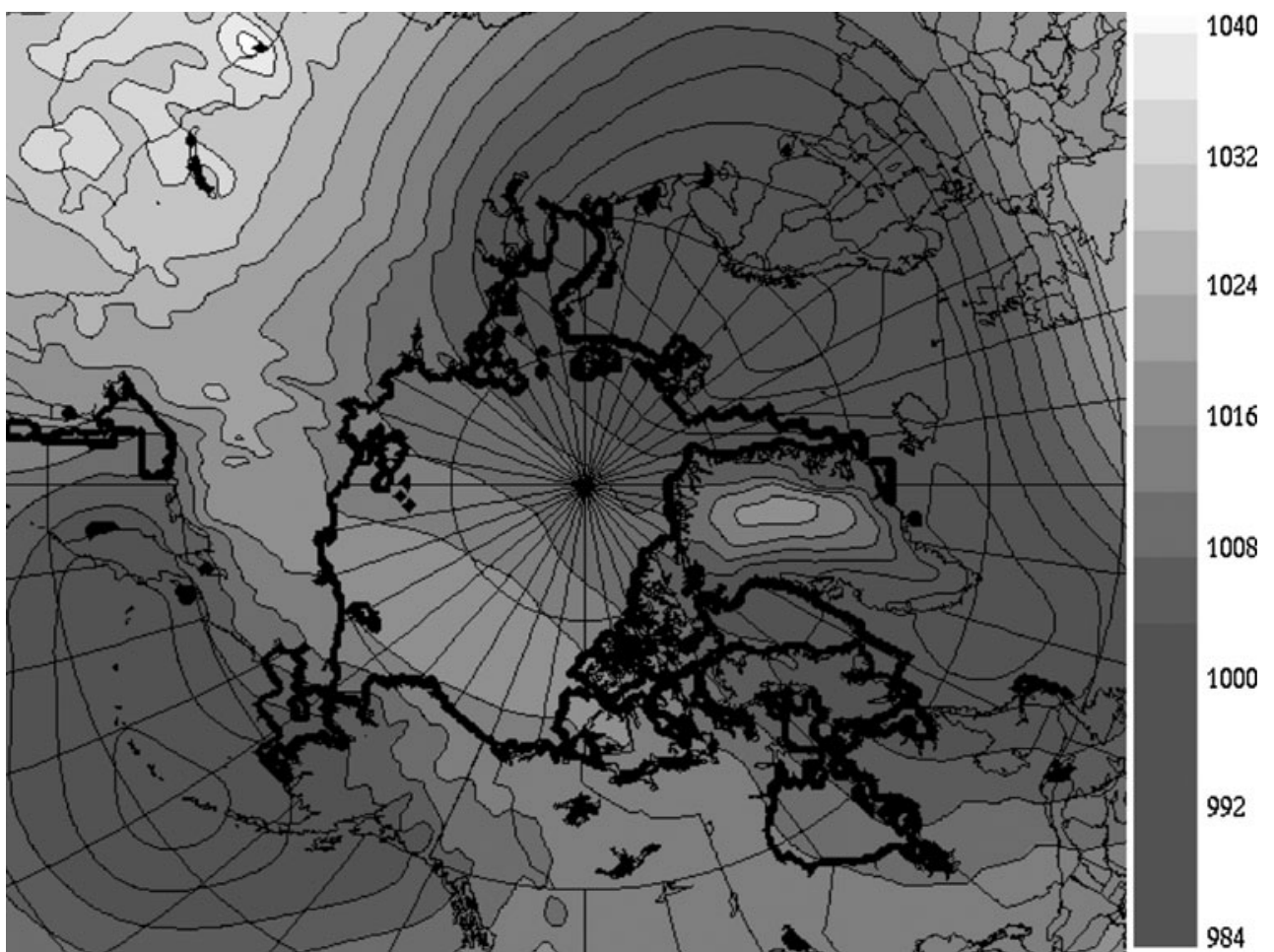

Table 2 January mean temperature at 850 hpa (T850), mean sea level pressure (MSLP), geopotential height at $500 \mathrm{hPa}$ (GZ500) averaged over the sea ice mask from the four aerosol scenario simulations and from the ECMWF analysis

\begin{tabular}{llllll}
\hline & Analysis & $\begin{array}{l}\text { NAT- } \\
\text { ON }\end{array}$ & $\begin{array}{l}\text { NAT- } \\
\text { OFF }\end{array}$ & $\begin{array}{l}\text { AC- } \\
\text { ON }\end{array}$ & $\begin{array}{l}\text { AC- } \\
\text { OFF }\end{array}$ \\
\hline MSLP (hPa) & $1,009.0$ & $1,012.6$ & $1,011.9$ & $1,012.8$ & $1,013.0$ \\
T850 (K) & 260.4 & 261.0 & 261.0 & 260.6 & 260.3 \\
$\begin{array}{l}\text { GZ500 } \\
(\text { dam })\end{array}$ & 521.0 & 524.0 & 523.6 & 523.7 & 523.4 \\
\hline
\end{tabular}

the ice saturation ratio significantly decreases when contact freezing is set to ON; while in the AC aerosol scenarios, contact freezing has no effect whatsoever on the ice saturation ratio. Some cloud water droplets freeze by contact nucleation in the NAT-ON scenario. Consequently, in an ice supersaturated environment, a part of the available water vapor deposits onto the surface of these ice crystals. This phenomenon contributes to reduce the relative humidity with respect to ice in the NAT-ON scenario to lower values when compared with the NAT-OFF scenario. Deposition ice nucleation strongly depends on the onset relative humidity with respect to ice. In the NAT-ON scenario, the threshold value required for deposition ice nucleation is not reached as often as in the NAT-OFF scenario due to the contribution of contact freezing. This reduces the deposition ice nucleation rate and subsequently slightly reduces the total number of active IN in the
Fig. 2 January mean vertical profiles of the (a) cloud ice mixing ratio $(* 1 . e-03 \mathrm{~g} / \mathrm{kg})$ and $(\mathbf{b})$ ice crystal concentration $\left(* 1 . \mathrm{e} 04 \mathrm{~m}^{-3}\right)$ averaged over the sea ice mask for the NAT-ON, NAT-OFF, AC-ON and ACOFF aerosol scenarios
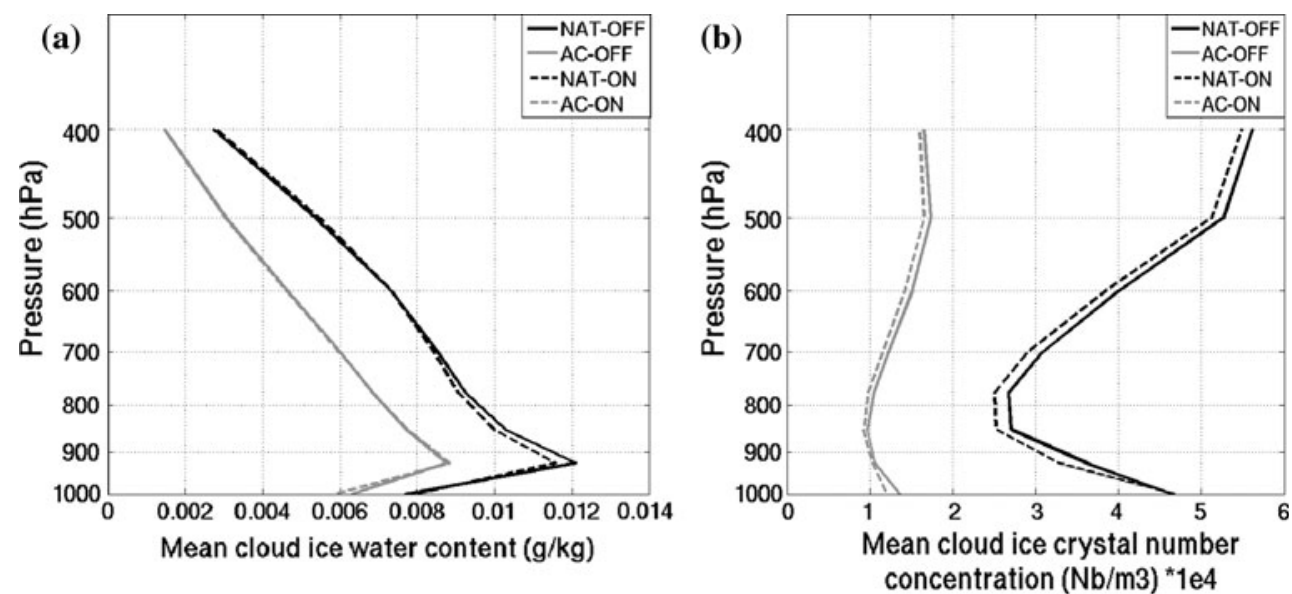
Fig. 3 January mean vertical profiles of the cloud liquid mixing ratio $\left(* 1 . e-03 \mathrm{~g} \mathrm{~kg}^{-1}\right)$ and droplet concentration sea ice mask for the NAT-ON, NAT-OFF, AC-ON and AC-OFF aerosol scenarios $\left(* 1 . \mathrm{e} 05 \mathrm{~m}^{-3}\right)$ averaged over the
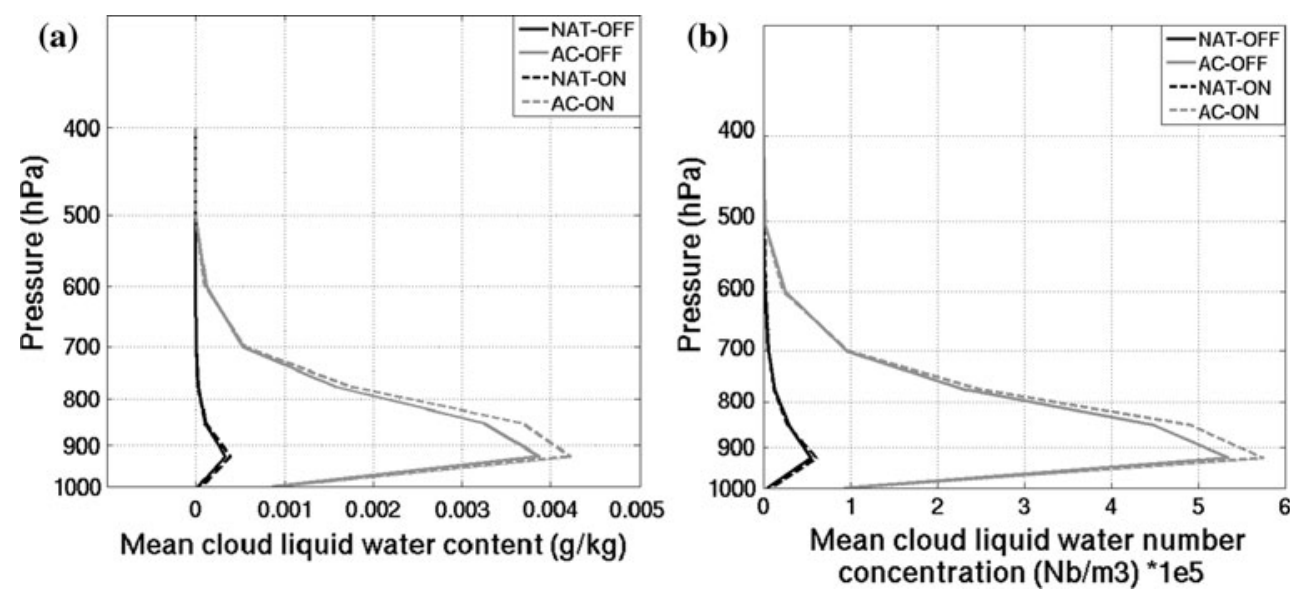

Fig. 4 January mean vertical profiles of the saturation ratio with respect to ice averaged over the sea ice mask for (a) NAT-ON and NAT-OFF and (b) AC-ON and AC-OFF aerosol scenarios

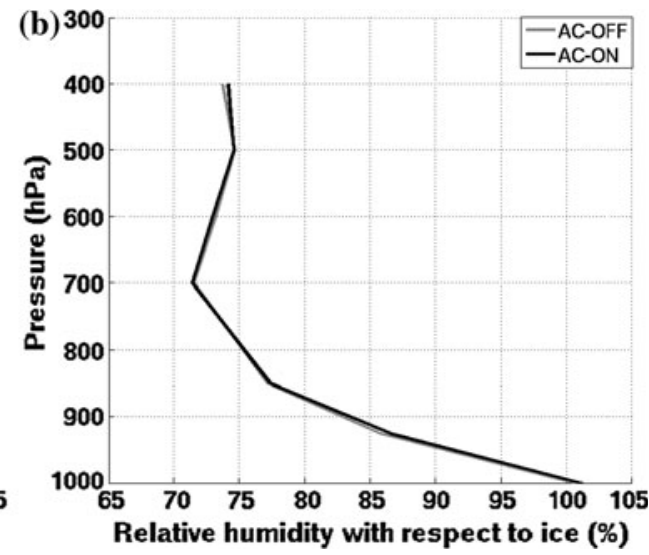

NAT-ON scenario. This finally results in a small decrease in the ice mixing ratio and ice crystal number concentration compared to NAT-OFF.

Figures 2 and 3 show that, in the AC aerosol scenarios (AC-ON and AC-OFF), contact freezing does not affect much the ice crystal number and mass concentration. However, the liquid water content and number concentration substantially increase when contact freezing is set to ON. The discussion about the NAT aerosol scenarios above is also valid for the $\mathrm{AC}$ aerosol scenarios. However, the nucleation rate of ice crystals by immersion is very small in the AC aerosol scenarios. Therefore, differences between $\mathrm{AC}-\mathrm{ON}$ and AC-OFF are reduced to very small values for the ice crystal mass and number concentrations. Since the ice supersaturation is large in the AC aerosol scenarios compared to the NAT aerosol scenarios, a decrease of the ice crystal number concentration has a substantial effect on the Wegener-Bergeron-Findeisen effect by limiting the deposition rate of water vapor on ice crystals, which depends on the concentration and size of ice crystals (Korolev and Mazin 2003). Therefore, the liquid water content remains larger in the AC-ON scenario compared to the AC-OFF scenario. The fact that the temperature is slightly warmer in the AC-ON scenario compared to AC-
OFF (see Fig. 7) also contributes to the increase of liquid water, since both immersion and contact freezing depends on temperature.

These results show that the contribution of contact freezing remains small in terms of cloud microstructure changes over the Arctic in January 2007. However, Girard et al. (2013) have shown that small changes in the mid and upper ice water content can have a significant impact in the CRF at the TOA over the Arctic during winter. Figure 5 shows the January mean CRF at the TOA produced by acid coating on the IN for the case where contact freezing is $\mathrm{ON}$ (AC-ON minus NAT-ON) and OFF (AC-OFF minus NATOFF). In both cases, there is a widespread area over most of the sea ice mask with negative CRF values reaching up to $-10 \mathrm{~W} \mathrm{~m}^{-2}$ locally. Negative CRF values correspond to places where the ice water path decrease is the largest in the acidic scenarios (AC-ON and AC-OFF) when compared with the uncoated aerosol scenarios (NAT-ON and NAT-OFF) (figure not shown). The CRF change at the TOA is strongly linked to the ice water path change (see Fig. 6) between the uncoated and acid scenarios. In the acid scenarios, the mid and upper troposphere is more transparent to infrared radiation coming from the lower levels and the surface leading to a negative CRF. Table 3 
Fig. 5 January mean cloud radiative forcing anomaly at the top of the atmosphere $\left(* 10 \mathrm{~W} \mathrm{~m}^{-2}\right)$ when contact nucleation is (a) ON (AC-ON minus NAT-ON) and (b) OFF (AC-OFF minus NAT-OFF)

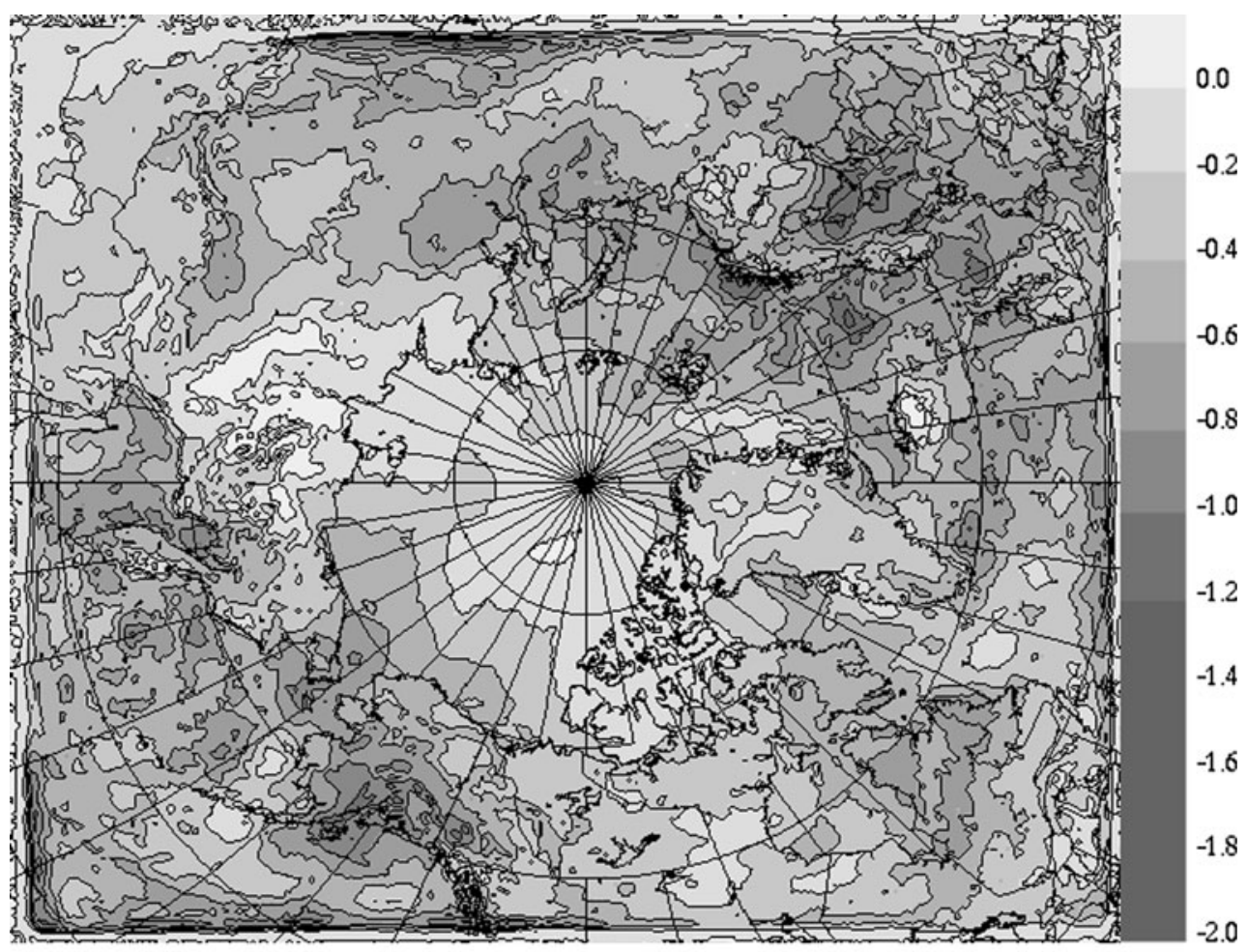

(a)

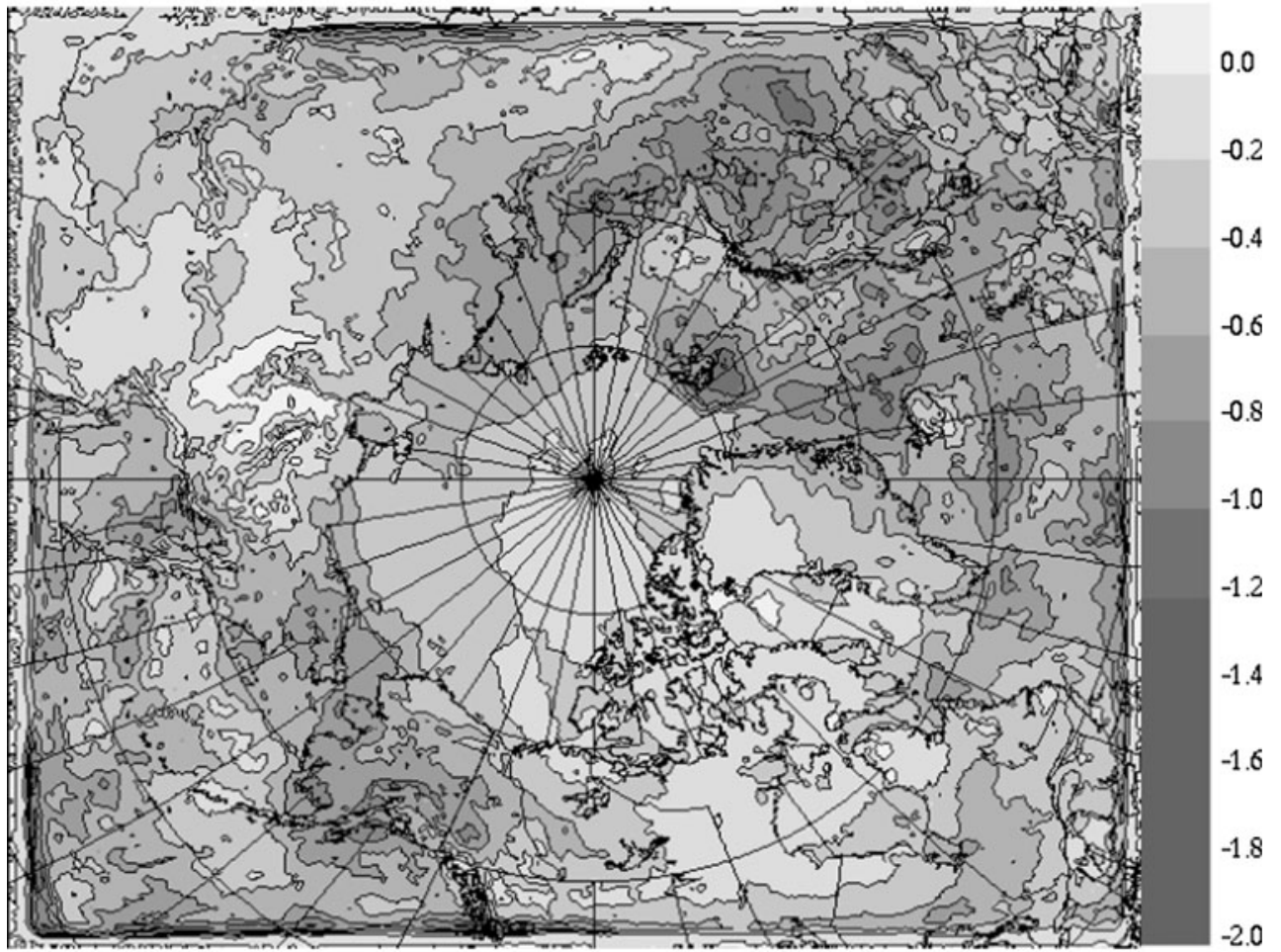

(b)

shows that the average CRF anomalies over the sea ice mask are -3.15 and $-3.20 \mathrm{~W} \mathrm{~m}^{-2}$ for the aerosol scenarios with and without contact freezing, respectively. The slightly larger CRF anomaly associated to AC-OFF and
NAT-OFF is due to the larger decrease of the ice water path in these scenarios compared to the ice water path decrease in the AC-ON and NAT-ON scenarios. At the surface, the CRF anomalies for both ON and OFF scenarios 

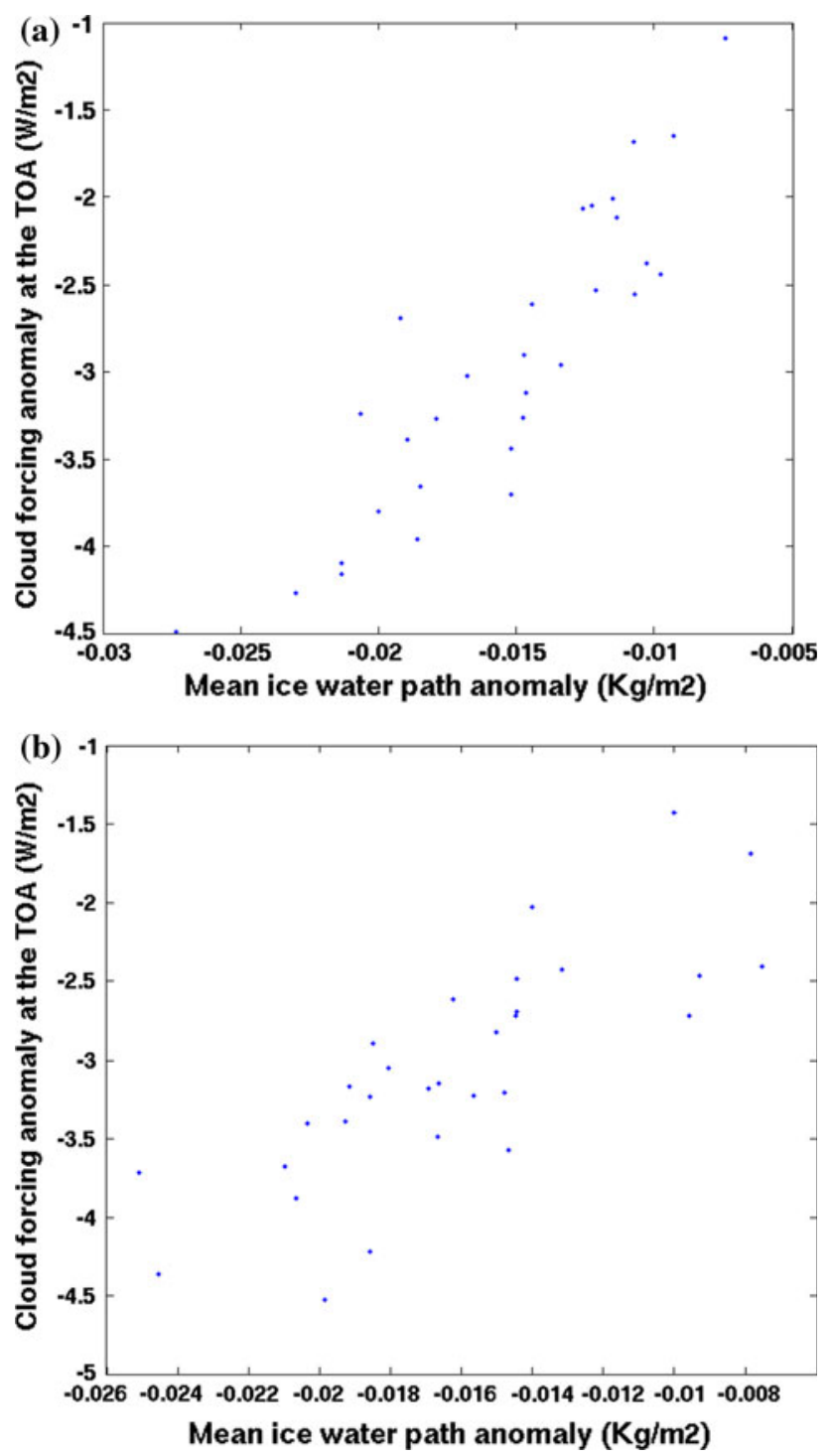

Fig. 6 Co-variation of the daily mean cloud forcing anomalies $\left(\mathrm{W} \mathrm{m}^{-2}\right)$ at the top of the atmosphere and the daily mean vertically integrated ice water path anomaly $\left(\mathrm{Kg} \mathrm{m}^{-2}\right)$ anomalies for the (a) $\mathrm{ON}$ aerosol scenarios and (b) the OFF aerosol scenarios. These values are averaged over the sea ice mask

Table 3 January mean ON anomalies (AC-ON minus NAT-ON) and OFF anomalies (AC-OFF minus NAT-OFF) averaged over the sea ice mask for the cloud radiative forcing at the top of the atmosphere (CRF TOA) and at the surface (CRF SUR) $\left(\mathrm{W} \mathrm{m}^{-2}\right.$ ) and temperature at $1,000,850$ and $500 \mathrm{hPa}(\mathrm{K})$

\begin{tabular}{lll}
\hline & ON anomalies & OFF anomalies \\
\hline CRF TOA $\left(\mathrm{W} \mathrm{m}^{-2}\right)$ & -3.15 & -3.20 \\
CRF SUR $\left(\mathrm{W} \mathrm{m}^{-2}\right)$ & -0.80 & -0.23 \\
T1000 (K) & -0.89 & -1.28 \\
T850 (K) & -0.78 & -1.32 \\
T500 (K) & -0.01 & -0.63 \\
\hline
\end{tabular}

remain slightly negative but close to 0 . In the AC scenarios, there is a positive contribution to the CRF from the increase of the liquid water path, which is compensated by the negative contribution of the colder clouds.

Figure 7 shows the January mean vertical profile of temperature for the $\mathrm{ON}$ and OFF aerosol scenarios. In these aerosol scenarios, the January mean cooling is maximum near the surface with values around $-1 \mathrm{~K}$ and gradually decreases upper in the troposphere to values close to $0 \mathrm{~K}$ (see Table 3). The magnitude and regions where the cooling is the largest mostly correspond to regions where the CRF anomalies are negative (see Fig. 5). Peak values close to $-3 \mathrm{~K}$ at $850 \mathrm{hPa}$ are located over Northern Alaska and Northern Siberia. Results show that the tropospheric cooling associated with acid coating on IN is slightly larger when contact freezing is neglected.

\section{Discussion}

Contact freezing differs from the three other heterogeneous ice nucleation processes (deposition, condensation-freezing, immersion freezing) in that a collision between an IN and a droplet is required for the nucleation of an ice crystal once the onset temperature for freezing is reached. The collision rate will depend on the IN concentration. On the other hand, deposition, immersion and condensationfreezing ice nucleation processes occur as soon as the onset relative humidity is reached with no additional required process such as collision with water droplets. Therefore, the relative contribution of contact freezing should strongly depend on the IN concentration, which partly determines the collision rate of IN with water droplets. In the simulations performed for this study, the Meyers et al. (1992) contact IN parameterization has been used. One may wonder whether results would have been different, if another approach or parameterization had been used. One possible and perhaps more realistic approach is the explicit simulation of dust and a more physically based nucleation rate by contact freezing based on laboratory studies.

There have been relatively few laboratory studies on contact freezing when compared with other ice nucleation modes (Pitter and Pruppacher 1973; Levin and Yankofsky 1983; Diehl and Mitra 1998; Diehl et al. 2002; Durant and Shaw 2005; Shaw et al. 2005; Svensson et al. 2009; Fornea et al. 2009; Ladino et al. 2011). These past studies have shown that most IN (such as mineral dust, bacteria, pollen and volcanic ash) nucleate ice at warmer temperatures than immersion freezing and deposition in the contact mode by up to $10{ }^{\circ} \mathrm{C}$, thus suggesting that contact freezing should dominate other heterogeneous ice nucleation modes. Contact freezing involves (1) the collision between an IN and a droplet and (2) the freezing of the droplet. The laboratory 
(a)

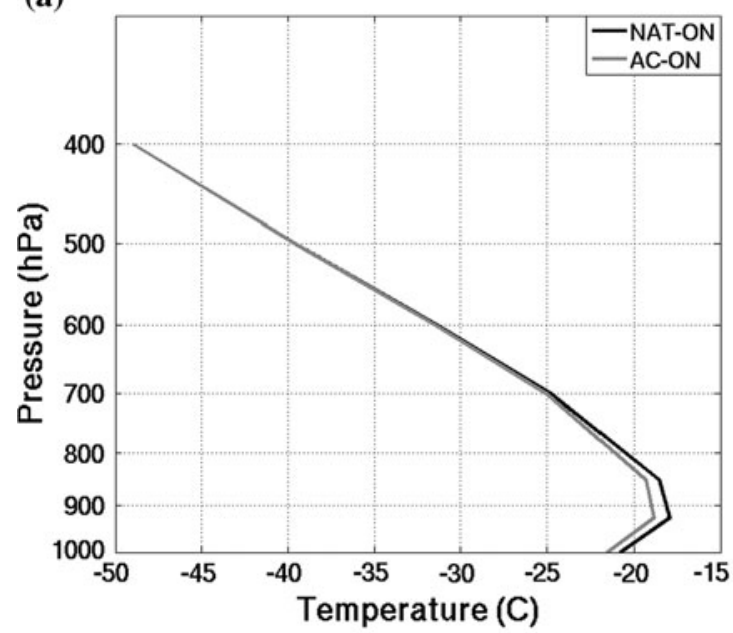

(c)

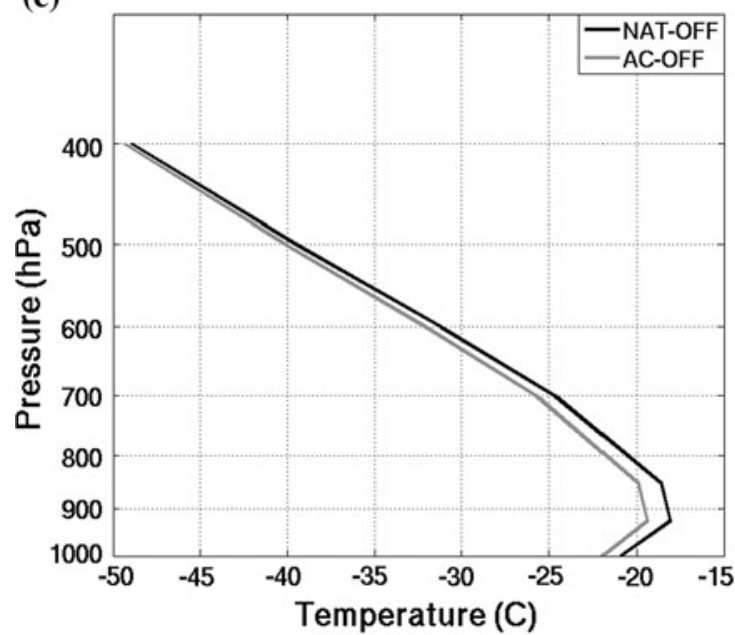

(b)

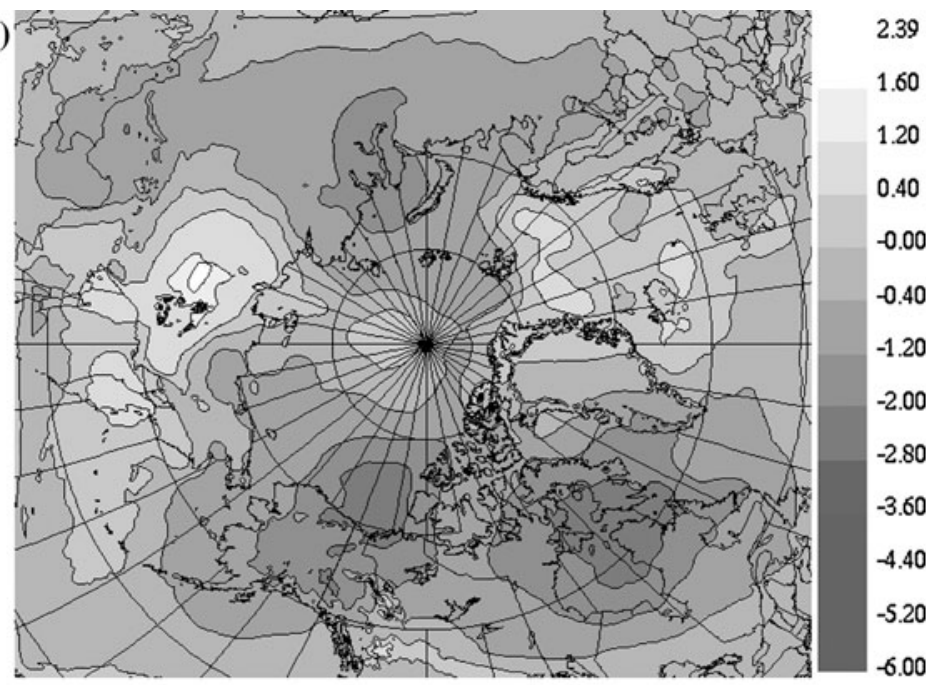

(d)

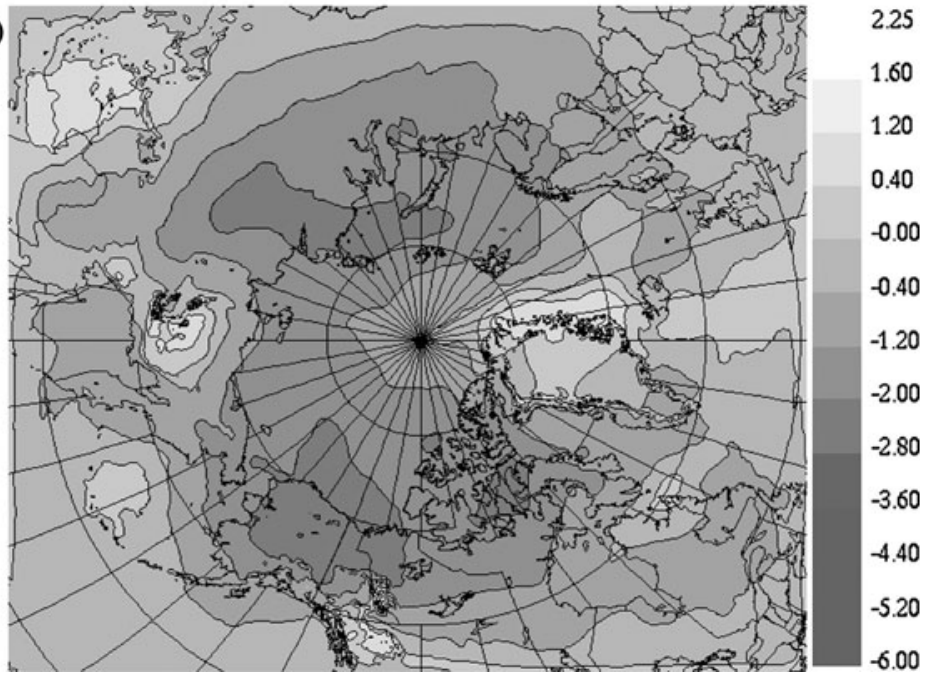

Fig. 7 January mean vertical profile of temperature for the (a) ON aerosol scenarios and (c) OFF aerosol scenarios averaged over the sea-ice mask. January mean temperature anomaly at $850 \mathrm{hPa}(\mathrm{K})$ for

studies cited above do not always allow evaluating the efficiency of the whole process. In some laboratory studies (e.g., Fornea et al. 2009), the cold plate methodology was adopted. In this experimental approach, the IN are mechanically put into contact with a droplet without the need for a collision. In other studies (e.g., Diehl et al. 2002), wind tunnel experiments were performed in which a collision with an IN is required for contact freezing. However, in most of the wind tunnel experiments, the aerosol concentration and sizes were not documented. In some studies, the aerosol and/or droplet sizes were not always relevant to the atmosphere. More recently, Ladino et al. (2011) performed a contact freezing experiment with kaolinite particles with documented droplet size, aerosol size and concentration relevant to the atmosphere. Results showed that a kaolinite concentration larger than $100 \mathrm{~cm}^{-3}$ the (b) ON aerosol scenarios (AC-ON minus NAT-ON) and (d) OFF aerosol scenarios (AC-OFF minus NAT-OFF)

was required to get a significant frozen fraction of droplets above the detection limit of their instrument. Such relatively large concentrations are required due to the low collision efficiency of water droplets with aerosol particles, which is of the order of 0.001 given their respective sizes (Wang et al. 2010).

According to the empirical relationship of Meyers et al. (1992), the IN concentration varies from $0.003 \mathrm{~cm}^{-3}$ at $-15{ }^{\circ} \mathrm{C}$ to $0.158 \mathrm{~cm}^{-3}$ at $-30{ }^{\circ} \mathrm{C}$. These values are three orders of magnitude smaller than the required IN concentration to get a significant frozen fraction of water droplets reported by Ladino et al. (2011). The results obtained in this study on the relatively small importance of contact freezing on the cloud microstructure are therefore in agreement with the laboratory study of Ladino et al. (2011). 
One may wonder whether the contact IN concentration given by the empirical relationship of Meyers et al. (1992) is realistic for the Arctic during winter. For a given temperature, the contact IN concentration depends on the total concentration of aerosols potentially acting as IN. Several IN such as pollen grains, bacteria and volcanic ash are giant aerosols, which are rapidly removed from the atmosphere either by dry or wet deposition. Mineral dust particles have smaller sizes and can be transported over longer distance. Most IN are composed by a large fraction of dust in the Arctic (Rogers et al. 2001; DeMott et al. 2003; Prenni et al. 2007; Richardson et al. 2007; Prenni et al. 2009). The concentration of dust particles is highly variable over the Arctic during winter. Observations taken during field experiments in the Arctic show dust mass concentrations ranging between 50 and 3,000 $\mathrm{ng} \mathrm{m}^{-3}$ (Winchester et al. 1984; Frenzén et al. 1994; Quinn et al. 2007) depending on the air mass origin. Assuming dust particles composed of kaolinite with a radius of $0.5 \mu \mathrm{m}$, these mass concentrations correspond to number concentrations no larger than $2.2 \mathrm{~cm}^{-3}$. According to these concentrations and the results obtained by Ladino et al. (2011), contact freezing should not be dominant except in cases where the dust concentration reaches values of more than $100 \mathrm{~cm}^{-3}$, which is significantly larger than the averaged concentration observed in the Arctic (e.g., Winchester et al. 1984). One may therefore expect that contact freezing would lead to the freezing of a significant fraction of water droplets when the dust concentration reaches unusually large values for the wintertime Arctic. It is however not clear what is the contact IN concentration in the Arctic since other aerosols may be good contact IN. Therefore, the contact IN threshold of $100 \mathrm{~cm}^{-3}$ required for a significant freezing rate of water droplets might be reached more often.

\section{Summary and conclusion}

In this research, the relative importance of contact and deposition ice nucleation in the formation of Arctic wintertime clouds in clean (uncoated aerosols) and polluted air masses (acid-coated aerosols) is evaluated for January 2007. Past studies (e.g., Girard et al. 2013) have shown that acid coating on deposition IN (in polluted air masses) substantially modifies the Arctic cloud microstructure and the CRF at the TOA during winter. The main objective of this research is to investigate the impact of high acid coating on contact IN on the microstructure and radiative forcing of Arctic wintertime clouds. The limited-area version of the GEM model is used to perform simulations over a domain covering the Arctic for January 2007.

Results show that contact freezing contributes to increase the cloud liquid water content and/or the droplet number concentration and decrease the cloud ice water content and/or the ice crystal number concentration in both clean and polluted air masses. This somewhat counter intuitive result is due to a negative feedback initiated by the nucleation of ice crystals by contact freezing, which contributes to decrease the relative humidity with respect to ice. Deposition (in the NAT scenario) and immersion (in the AC scenario) ice nucleation strongly depends on the ice supersaturation. Therefore, when contact freezing is $\mathrm{ON}$, the nucleation rate of ice crystals by deposition (in the NAT scenario) or immersion (in the AC scenario) decreases. Results show that these changes in the cloud microstructure have a negligible effect on the CRF at the TOA over the Arctic during January 2007. Therefore, according to our simulation results, in the event that contact IN is altered by acid coating (like deposition IN), the impact on the Arctic wintertime cloud and radiation would be negligible.

Additional simulations are needed to be performed to confirm the results obtained in this study. Simulations covering other wintertime and springtime months and also a more realistic aerosol representation (e.g., from assimilated observations) will be required to capture high dust concentrations that may occur over the Arctic during haze events and also dust particle size, sources and sinks. Finally, more theoretical, laboratory and in situ studies are strongly needed on contact ice nucleation to better evaluate its importance on the cloud microstructure and radiation.

Acknowledgments This research was funded by the Natural Sciences and Engineering Research Council of Canada (NSERC) and the Ministère du Développement Économique, de l'Innovation et de l'Exportation (MDEIE) of Quebec.

Open Access This article is distributed under the terms of the Creative Commons Attribution License which permits any use, distribution, and reproduction in any medium, provided the original author(s) and the source are credited.

\section{References}

Ansmann A, Mattis I, Müller D, Wandinger U, Radlach M, Althausen D (2005) Ice formation in Saharan dust over central Europe observed with temperature/humidity/aerosol Raman lidar. J Geophys Res 110:D18S12. doi:10.1029/2004JD005000

Ansmann A, Tesche M, Seifert P, Althausen D, Engelmann R, Fruntke J, Wandinger U, Mattis I, Müller D (2009) Evolution of the ice phase in tropical altocumulus: SAMUM lidar observations over Cape Verde. J Geophys Res 114:D17208. doi:10. 1029/2008JD011659

Archuleta CM, DeMott PJ, Kreidenweis SM (2005) Ice nucleation by surrogates for atmospheric mineral dust and mineral dust/sulfate particles at cirrus temperatures. Atmos Chem Phys 5:2617-2634

Baker BA, Lawson RP (2006) In situ observations of microphysical properties of wave, cirrus and anvil clouds. Part 1: wave clouds. J Atmos Sci 63:3160-3185 
Barrie LA, Olson MP, Oikawa KK (1989) The flux of anthropogenic sulphur into the Arctic from mid-latitudes. Atmos Environ 23:2502-2512

Beard KV (1992) Ice initiation in warm-base convective clouds: an assessment of microphysical mechanisms. Atmos Res 28:125-152

Bigg EK (1953) The formation of atmospheric ice crystals by the freezing of droplets. Q J Roy Meteorol Soc 79:510-519

Bigg EK (1980) Comparison of aerosol at four baseline atmospheric monitoring stations. J Appl Meteorol 19:521-533

Bourgeois Q, Bey I (2011) Pollution transport efficiency toward the Arctic: sensitivity to aerosol scavenging and source regions. J Geophys Res 116:D08213. doi:10.1029/2010JD015096

Cantrell W, Shaw G, Benner R, Veazey D (1997) Evidence for sulfuric acid coated particles in the Arctic air mass. Geophys Res Lett 24(23):3005-3008. doi:10.1029/97GL02656

Chernoff DI, Bertram AK (2010) Effects of sulfate coatings on the ice nucleation properties of a biological ice nucleus and several types of minerals. J Geophys Res 115:D20205. doi:10.1029/ 2010JD014254

Cooper WA (1986) Ice initiation in natural clouds, in precipitation enhancement-a scientific challenge, edited by R. G. Braham Jr. Meteorol Monogr 443:29-32

Cooper WA (1995) Ice formation in wave clouds: observed enhancement during evaporation. Proc Conf Cloud Phys Am Meteorol Soc Dallas Tex 147-152

Côté J, Gravel S, Méhot A, Patoine A, Roch M, Staniforth A (1998) The operational CMC-MRB global environmental multiscale (GEM) Model. Part I. Design considerations and formulation. Mon Weather Rev 126:1373-1395

Cotton RJ, Field PR (2002) Ice nucleation characteristics of an isolated wave cloud. Q J R Meteorol Soc 128:2417-2437

Cotton WR, Tripoli GJ, Rauber RM, Mulvihill EA (1986) Numerical simulation of the effects of varying ice crystal nucleation rate and aggregation processes on orographic snowfall. J Climate Appl Meteorol 25:1658-1680

Cziczo DJ, Froyd KD, Gallavardin SJ, Möhler O, Benz S, Saathoff H, Murphy DM (2009) Deactivation of ice nuclei due to atmospherically relevant surface coatings. Environ Res Lett. doi:10. 1088/1748-9326/4/4/044013

DeMott PJ, Meyers MP, Cotton WR (1994) Parameterization and impact of ice initiation processes relevant to numerical model simulations of cirrus clouds. J Atmos Sci 51:77-90

DeMott PJ, Cziczo DJ, Prenni AJ, Murphy DM, Kreidenweis SM et al (2003) Measurements of the concentration and composition of nuclei for cirrus formation. Proc Natl Acad Sci USA 100:14655-14660

Diehl K, Mitra SK (1998) A laboratory study of the effects of a kerosene-burner exhaust on ice nucleation and the evaporation rate of ice crystals. Atmos Environ 32:3145-3151

Diehl K, Matthias-Maser S, Jaenicke R, Mitra S (2002) The ice nucleating ability of pollen, Part 2: laboratory studies in immersion and contact freezing modes. Atmos Res 61:125-133

Du P, Girard E, Bertram AK, Shupe MD (2011) Modeling of the cloud and radiation processes observed during SHEBA. Atmos Res 101:911-927

Durant AJ, Shaw RA (2005) Evaporation freezing by contact nucleation inside-out. Geophys Res Lett 32:L20814. doi:10. 1029/2005GL024175

Eastwood ML, Cremel S, Wheeler M, Murray BJ, Girard E, Bertram AK (2008) Ice nucleation on mineral dust particles: onset conditions, nucleation rate and contact angles. J Geophys Res. doi:10.1029/2008JD010639

Eastwood ML, Cremel S, Wheeler M, Murray BJ, Girard E, Bertram AK (2009) The effect of sulphuric acid and ammonium sulfate coatings on the ice nucleation properties of kaolinite particles. Geophys Res Let. doi:10.1029/2008GL035997

Ettner M, Mitra SK, Borrmann S (2004) Heterogeneous freezing of single sulfuric acid solution droplets: laboratory experiments utilizing an acoustic levitator. Atmos Chem Phys 4:1925-1932

Field PR et al (2001) Ice nucleation in orographic wave clouds: measurements made during INTACC. Q J R Meteorol Soc 127:1493-1512

Field PR, Möhler O, Connolly P, Krämer M, Cotton R, Heymsfield AJ, Saathoff H, Schnaiter M (2006) Some ice nucleation characteristics of Asian and Saharan desert dust. Atmos Chem Phys 6:2991-3006

Fisher JA, Jacoba DJ, Wanga Q, Bahreinib R, Carougea CC, Cubisonb MJ, Dibbe JE, Diehlf T, Jimenezb JL, Leibenspergera EM, Meindersh MBJ, Pyei HOT, Quinn PK, Sharmak S, Van Donkelaarl A, Yantoscaa RM (2011) Sources, distribution, and acidity of sulfate-ammonium aerosol in the Arctic in winterspring. J Atmos Environ. doi:10.1016/08.030

Fletcher NH (1962) Physics of Rain Clouds. Cambridge University Press, London, p 396

Fornea AP, Brooks SD, Dooley JB, Saha A (2009) Heterogeneous freezing of ice on atmospheric aerosols containing ash, soot, and soil. J Geophys Res 114:D13201. doi:10.1029/2009JD011958

Frenzén LG, Hjelmroos M, Kallberg P, Brorström-Lundén E, Juntto S, Savolainen AL (1994) The yellow snow episode of northern Fennoscandia, March 1991-A case study of long-distance transport of soil, pollen and stable organic compounds. Atmos Environ 28:3587-3604

Girard E, Bekcic B (2005) Sensitivity of an arctic regional climate model to the horizontal resolution during winter: implications for aerosol simulation. Int J Clim 25:1455-1471

Girard E, Blanchet J-P, Dubois Y (2005) Effects of sulphuric acid aerosols on wintertime low-level atmospheric ice crystals, humidity, and temperature at Alert, Nunavut. Atmos Res 73:131-148

Girard E, Dueymes G, Du P, Bertram AK (2013) Assessment of the effects of acid-coated ice nuclei on the Arctic cloud microstructure, atmospheric dehydration, radiation and temperature during winter. Int J Clim 33:599-614. doi:10.1002/joc.3454

Harrington JY, Olsson PQ (2001) A method for the parameterization of cloud optical properties in bulk and bin microphysical models: implications for Arctic cloudy boundary layers. Atmos Res 57:51-80

Harrington JY, Reisen T, Cotton WR, Kreidenweis SM (1999) Cloudresolving simulations of Arctic stratus. Part II: transition-season clouds. Atmos Res 51:45-75

Hobbs PV, Rangno AL (1985) Ice particle concentrations in clouds. J Atmos Sci 42:2523-2549

Hurrell JW, Hack JJ, Shea D, Caron JM, Rosinski J (2008) A new sea surface temperature and sea ice boundary dataset for the community atmosphere model. J Clim 21:5145-5153. doi:10. 1175/2008JCLI2292.1

Jouan C, Girard E, Pelon J, Gultepe I, Delanoë J, Blanchet J-P (2012) Characterization of Arctic optically thin ice clouds observed during ISDAC. J Geophys Res 117:D23207. doi:10.1029/ 2012JD017889

Jouan C, Pelon J, Girard E, Ancellet G, Blanchet J-P, Delanoë J (2013) On the relationship between Arctic ice clouds and polluted air masses over the north slope of Alaska in April 2008. Atmos Chem Phys Discuss 13:4331-4389. doi:10.5194/acpd-134331-2013

Knopf DA, Koop T (2006) Heterogeneous nucleation of ice on surrogates of mineral dust. J Geophys Res. doi:10.1029/ 2005JD006894

Korolev AV, Mazin IP (2003) Supersaturation of water vapor in clouds. J Atmos Sci 60:2957-2974 
Ladino L, Stetzer O, Lüönd F, Welti A, Lohmann U (2011) Contact freezing experiments of kaolinite particles with cloud droplets. J Geophys Res 116:D22202. doi:10.1029/2011JD015727

Law KS, Stohl A (2007) Arctic air pollution: origins and impacts. Science. doi:10.1126/science. 1137695

Levin Z, Yankofsky SA (1983) Contact versus immersion freezing of freely suspended droplets by bacterial ice nuclei. J Clim Appl Meteorol 22:1964-1966

Li J, Barker W (2005) A radiation algorithm with correlated-K distribution. Part I: local thermal equilibrium. J Atmos Sci 62:286-309

Meyers MP, DeMott PJ, Cotton WR (1992) New primary icenucleation parameterizations in an explicit cloud model. J Appl Meteorol 31:708-721

Milbrandt JA, Yau MK (2005) A multimoment bulk microphysics parameterization. Part I: analysis of the role of the spectral shape parameter. J Atmos Sci 62:3051-3064

Morrison H, Shupe MD, Pinto JO, Curry JA (2005) Possible roles of ice nucleation mode and ice nuclei depletion in the extended lifetime of Arctic mixed-phase clouds. Geophys Res Lett 32:L18801. doi:10.1029/2005GL023614

Niedermeier D, Hartmann S, Shaw RA, Covert D, Mentel TF, Schneider J, Poulain L, Reitz P, Spindler C, Clauss T, Kiselev A, Hallbauer E, Wex H, Mildenberger K, Stratmann F (2010) Heterogeneous freezing of droplets with immersed mineral dust particles-measurements and parameterization. Atmos Chem Phys 10:3601-3614. doi:10.5194/acp-10-3601-2010

Noilhan J, Planton S (1989) A simple parameterization of land surface processes for meteorological models. Mon Weather Rev 117:536-549

Pitter RL, Pruppacher HR (1973) A wind tunnel investigation of freezing of small water drops falling at terminal velocity in air. Q J Roy Meteorol Soc 99:540-550

Prenni AJ, Harrington JY, Tjernström M, DeMott PJ, Avramov A et al (2007) Can ice-nucleating aerosols affect Arctic seasonal climate? Bull Am Meteorol Soc 88:541-550

Prenni AJ, DeMott PJ, Rogers DC, Kreidenweis SM, McFarquar GM, Zhang G, Poellot MR (2009) Ice nuclei characteristics form M-PACE and their relation to ice formation in clouds. Tellus 61B:436-448

Pruppacher HR, Klett JD (1997) Microphysics of clouds and precipitation. Kluwer Academic Publishers, Dordrecht

Quinn PK, Shaw G, Andrews E, Dutton EG, Ruoho-Airola T, Gong SL (2007) Arctic haze: current trends and knowledge gaps. Tellus 59B:99-114

Rangno AL, Hobbs PV (1994) Ice particle concentrations and precipitation development in small continental cumuliform clouds. Q J R Meteorol Soc 120:573-601
Richardson MS, DeMott PJ, Kreidenweis SM, Cziczo DJ, Dunlea EJ et al (2007) Measurements of heterogeneous ice nuclei in the western United States in springtime and their relation to aerosol characteristics. J Geophys Res 112:D02209

Rinke A, Dethloff K (2000) On the sensitivity of a regional Arctic climate model to initial and boundary conditions. Clim Res 14:101-113

Rinke A, Dethloff K, Fortmann M (2004) Internal variability in arctic regional climate simulations: case study for the SHEBA year. Clim Res 27:197-209

Rogers DC, DeMott PJ, Kreidenweis SM (2001) Airborne measurements of tropospheric ice-nucleating aerosol particles in the Arctic spring. J Geophys Res 106:15053-15063

Salam A, Lohmann U, Lesins G (2007) Ice nucleation of ammonia gas exposed montmorillonite mineral dust particles. Atmos Chem Phys 7:3923-3931

Schnell RC (1984) Arctic haze and the Arctic gas and Aerosol sampling program (AGASP). Geophys Res Lett 11:361-364

Shaw GE (1995) The Arctic haze phenomenon. Bull Am Meteorol Soc 76:2403-2413

Shaw R, Durant A, Mi Y (2005) Heterogeneous surface crystallization observed in undercooled water. J Phys Chem B 109(20):9865-9868

Sullivan RC, Petters MD, DeMott PJ, Kreidenweis SM, Wex H, Niedermeier D, Hartmann S, Clauss T, Stratmann F, Reitz P, Schneider J, Sierau B (2010) Irreversible loss of ice nucleation active sites in mineral dust particles caused by sulphuric acid condensation. Atmos Chem Phys 10:11471-11487. doi:10.5194/ acp-10-11471-2010

Svensson EA, Delval C, von Hessberg P, Johnson MS, Pettersson JBC (2009) Freezing of water droplets colliding with kaolinite particles. Atmos Chem Phys 9:4295-4300. doi:10.5194/acp-94295-2009

Walko RL, Cotton WR, Meyers MP, Harrington JY (1995) New RAMS cloud microphysics: part I: the one-moment scheme. Atmos Res 38:1735-1748

Wang X, Zhang L, Moran MD (2010) Uncertainty assessment of current size-resolved parameterizations for below-cloud scavenging by rain. Atmos Chem Phys 10:5685-5705

Winchester JW, Li SM, Fan SM, Schnell RC, Bodhaine BA, Naegele SS (1984) Coarse particle soil dust in arctic aerosols, Spring 1983. Geophys Res Lett 11:995-998

Yli-Tuomi T, Vanditte L, Hopke PK, Shamasuzzoha Basunia M, Landsberger S, Viisanen Y, Paatero J (2003) Composition of the finnish Arctic aerosol: collection and analysis of historic filter samples. Atmos Environ 37:2355-2364 